\title{
Mechanical Harvesting and Tree Health ${ }^{1}$
}

Richard S. Buker, James P. Syvertsen, Jacqueline K. Burns, Fritz M. Roka, William M. Miller, Masoud Salyani and Galen K. Brown ${ }^{2}$

A typical concern voiced over mechanical citrus harvesters is "Do they harm trees?" Observing mechanical citrus harvesters reveals they can remove leaves, branches, bark, and sometimes immature Valencia fruit. This publication was designed to inform decision makers on the impacts of tree injury on the health and longevity of citrus trees. This publication addresses only one of several components that could influence your decision to mechanically harvest citrus trees-effects of mechanical harvesting on tree health. There are benefits to mechanically harvesting a citrus grove. The authors of this publication recommend reviewing other IFAS publications on mechanical harvesting before making a decision about mechanical citrus harvesters.

Listed below are some typical questions and answers about the impact of mechanical harvesters on citrus tree health and longevity. These statements are made from published research and research conducted on mechanical harvesters over a thirty-year period. The trees used in these experiments were described as generally healthy. Trees experiencing drought stress, Diaprepes feeding, hollow heart, or scions/rootstock incompatibility may respond unexpectedly.
Q: What are the long-term effects of tree shakers on yield?

A: Studies with well-managed trees that were mechanically harvested annually with trunk shakers for 5 consecutive years in the 1960s and 1980s, as well as studies during 5 years in the late 1990s, did not show reduction in fruit yield. Groves with healthy trees harvested commercially in Florida for about 10 years with trunk shakers have not shown any negative effect on yield.

Q: What about leaf loss?

A: Mechanical harvesting, whether preformed by trunk shakers or canopy shakers, can cause many leaves to drop off the tree. Data from defoliation studies have shown that remaining leaves can compensate for leaf loss, allowing the tree to maintain growth. Ongoing studies removing up to $50 \%$ of the leaves resulted in no reductions in yield one year after leaves were removed. Major leaf loss as a result of mechanical harvesting prior to a freeze may increase freeze damage.

1. This document is HS961, one of a series of the Horticultural Sciences Department, Florida Cooperative Extension Service, Institute of Food and Agricultural Sciences, University of Florida. Published July 2004. Visit the EDIS Web site at http://edis.ifas.ufl.edu.

2. R.S. Buker, assistant professor, J.P. Syvertsen, professor, J.K. Burns, professor; Citrus REC, Lake Alfred, FL; F.M. Roka, associate professor, Southwest Florida REC, Immokalee, FL; W.M. Miller, professor, M. Salyani, professor; Citrus REC, Lake Alfred, Florida; Horticultural Sciences Department; G.K. Brown, Florida Department of Citrus; Cooperative Extension Service, Institute of Food and Agricultural Sciences, University of Florida, Gainesville, 32611

The Institute of Food and Agricultural Sciences (IFAS) is an Equal Employment Opportunity - Affirmative Action Employer authorized to provide research, educational information and other services only to individuals and institutions that function without regard to race, creed, color, religion, age, disability, sex, sexual orientation, marital status, national origin, political opinions or affiliations. For information on obtaining other extension publications, contact your county Cooperative Extension Service office. Florida Cooperative Extension Service / Institute of Food and Agricultural Sciences / University of Florida / Larry R. Arrington, Interim Dean 
Q: What about roots?

A: A number of surface roots may become exposed during trunk shaking, especially during longer duration shake times. Root pruning studies that removed up to $50 \%$ of the total root mass of healthy well-watered trees, have shown that remaining roots can compensate for root loss. The root system rapidly regrows to establish an appropriate balance between roots and shoots. In Florida citrus groves where trunk shakers were continuously used to harvest for over 10 years and a small number of roots exposed under trees, yield was not affected.

Q: What about bark injury ("barking") on the trunk?

A: Early models of multidirectional orbital trunk shakers, improperly padded clamps, or operation by less-experienced individuals, did remove sections of bark. Nonetheless, there is no evidence of increased tree mortality from mechanically harvested trees than from hand-harvested trees. This barking has been minimized by using linear-direction trunk shakers with proper clamp pads and experienced operators. Trunk girdling experiments, where rings of bark were removed from around the entire trunk and allowed to heal, actually increased yield with no apparent long-term tree injury.

Q: What about bark injury on branches from canopy shakers?

A: Branch injury from canopy shakers can occur, however, it is likely to be most severe in the first year of mechanical harvesting. Less canopy damage is likely to occur in subsequent years. In subsequent years, the branch injury is no worse than ladder damage from hand picking operations. However, the branch injury from canopy shakers is more common than ladder damage.

Q: If I see bark injury, what should I do?

A: In healthy citrus trees, there have been no reports of negative effects of barking on tree health. Any bark wounds should be allowed to dry out and heal naturally. Remedial "pruning scar seal" treatments should be avoided since they can trap pathogens under the seal over the wound. Avoid soil contamination of wounds. Recommended practices should be followed to decontaminate all grove equipment with quaternary ammonium to prevent the spread of canker.

Q: What about removal of green fruit in late season Valencia?

A: Ongoing studies are evaluating the impact of mechanical harvesting on the following year's Valencia crop. Mechanically harvesting citrus up to May 10 with trunk shakers or May 20 with canopy shakers, has not reduced yields the following year. The results of these studies are similar to yield results obtained by commercial growers who have now accumulated as much as 10 years of experience. The future use of fruit abscission chemicals is expected to avoid yield reductions of late-season Valencia.

The bottom line is research studies where trees have been repeatedly harvested mechanically for 5 years and commercial harvesting experience have shown no reductions in yield or tree health for Hamlin, Pineapple, Parson Brown, and early-season Valencia oranges.

\section{References}

Whitney, J. D., D. B. Churchill, and S. L. Hedden. 1986. A five-year study of orange removal with trunk shakers. Proc. Fla. State Hort. Soc. 99:40-44.

Hedden, S. L. and G. E. Coppock. 1968. Effects of the tree shaker harvest system on subsequent citrus yields. Proc. Fla. State Hort. Soc. 81:48-52. 